\title{
MicroRNA-related sequence variations in human cancers
}

\author{
A. Wojcicka $\cdot$ A. de la Chapelle $\cdot$ K. Jazdzewski
}

Received: 6 November 2013 / Accepted: 7 November 2013 / Published online: 19 November 2013

(C) The Author(s) 2013. This article is published with open access at Springerlink.com

\begin{abstract}
MicroRNAs are emerging as a most promising field in basic and translational research, explaining the pathogenesis of numerous human diseases and providing excellent tools for their management. This review considers the effects of microRNA sequence variations and their implication in pathogenesis and predisposition to human cancers. Although the role of microRNAs still remains to be elucidated, functional, and populational studies indicate that microRNA variants are important factors underlying the process of carcinogenesis. Further understanding of the cellular and molecular basis of microRNA action will lead to the identification of their new target genes and microRNA-regulated pathways. As a consequence, novel models of cancer pathogenesis can be proposed, and serve as a basis for elucidation of new prognostic and diagnostic tools for human cancers.
\end{abstract}

\section{MicroRNA action}

The discovery of microRNAs (miRNAs, miRs) was a milestone in our quest to understand the pathogenesis of

\footnotetext{
A. Wojcicka $\cdot$ K. Jazdzewski $(\bowtie)$

Genomic Medicine, Department of General, Transplant, and Liver Surgery, Medical University of Warsaw, Zwirki i Wigury 61, 02-091 Warsaw, Poland

e-mail: krystian.jazdzewski@wum.edu.pl

A. Wojcicka $\cdot$ K. Jazdzewski

Laboratory of Human Cancer Genetics, Centre of New

Technologies, CENT, University of Warsaw,

02-089 Warsaw, Poland

e-mail: awojcicka@wum.edu.pl

A. de la Chapelle

Human Cancer Genetics Program, Comprehensive Cancer

Center, Ohio State University, Columbus, OH 43210, USA
}

numerous human cancers. Deregulation of gene expression observed in malignancies can nowadays be explained by the action of short, endogenous non-coding RNAs-microRNAs. The cellular "microcosm" is emerging as a most promising field in translational research, providing excellent diagnostic, prognostic and therapeutic tools for the management of human diseases.

MicroRNAs are encoded all over the human genomein intergenic regions as well as within introns or exons of protein-coding genes (Rodriguez et al. 2004). Primary miRNA transcripts are processed to produce miRNA precursors (pre-miRNAs) that fold into specific secondary structures of hairpins. Pre-miRNAs are further cleaved, and mature microRNAs are produced from one or both arms of the hairpin. The produced miRs are referred to as miR$5 p$ and miR-3p, depending on the arm from which they are cleaved (Bartel 2009). In animals, miRNAs act mainly through annealing to $3^{\prime}$ untranslated regions ( $3^{\prime}$ UTRs) of gene transcripts, leading to inhibition of further steps of gene expression. This interaction depends on Watson-Crick complementarity between the target $3^{\prime} \mathrm{UTR}$ sequence and the "seed" region, located between the second and eighth nucleotide of the mature miRNA (Friedman et al. 2009; Grimson et al. 2007). It is believed that microRNAs regulate the expression of approximately $50 \%$ of human genes (Krol et al. 2010).

To date, there are 1,872 precursors and 2,578 mature miRNAs annotated and described in humans (miRbase release 20) (Griffiths-Jones et al. 2008; Kozomara and Griffiths-Jones 2011). According to a recent analysis, the premicroRNA regions include 1,940 SNPs. Moreover, 414,510 other human SNPs might potentially influence miR:mRNA interactions, causing either loss or creation of a miRNAbinding site (Liu et al. 2012). Considering the prevalence of microRNA-mediated gene regulation, sequence variations 
in miRs can significantly contribute to changes in important cellular pathways and thus underlie diseases. Genetic variations in microRNA sequences are unique as they can influence both the expression levels and functionality of a miRNA. A SNP located in the crucial "seed" sequence of a miR affects its complementarity with target genes and leads to deregulation of multiple cellular pathways. Moreover, since the expression of miRs is highly tissue and diseasespecific, changes within the miRNA sequence can indeed specifically predispose to cancers of particular organs and mediate different molecular changes in different tissues (de la Chapelle and Jazdzewski 2011).

The first microRNAs whose aberrations were linked to the pathogenesis of cancer were miR-15a and miR16-1, lost in the majority of B cell chronic lymphocytic leukemia (CLL) patients due to the deletion of chromosome 13q14 (Calin et al. 2002). Later studies revealed an alternative mechanism leading to severe downregulation of the miRs in a few cases of CLL, namely, a germline $\mathrm{C} \rightarrow \mathrm{T}$ substitution downstream of the miR-16-1 hairpin (Calin et al. 2005). The explanation of the downregulation was unknown till recently, when Auyeung et al. (2013) showed that specific sequence determinants, including a recognition site for the splicing factor SRp20 located downstream of most pri-miRNA hairpins, are required for efficient processing and maturation of microRNAs in human cells. The deleterious mutation lowers the expression of miR-16-1 and leads to CLL through the disruption of SRp20 binding site.

\section{SNPs in microRNA genes}

The first reports on variations in microRNA sequences were published more than 10 years after the discovery of microRNAs and were first proposed to have no effect on the functionality of miRs (Iwai and Naraba 2005; Saunders et al. 2007). Naturally occurring sequence variation in a miRNA precursor that resulted in reduced processing, lowered levels, and disrupted function of a mature miRNA was first reported for a viral miR-K5 (Gottwein et al. 2006) and, subsequently, for human miR-125a (Duan et al. 2007) and miR-146a (Jazdzewski et al. 2008).

All these studies proved that a single nucleotide polymorphism that leads to disruption of base pairing in the hairpin stem, results in a dramatically impaired processing and downregulation of the mature microRNA. The rs 12975333 in miR-125a results in a $\mathrm{G} \rightarrow \mathrm{T}$ change at the eighth nucleotide of the mature miR and severely reduces its production (Duan et al. 2007). The polymorphism was shown to be associated with a significantly increased risk for breast cancer in Antwerp ( $\mathrm{Li}$ et al. 2009). It was proposed that lowered levels of the mature miR-125a lead to overexpression of its target gene, HER2, whose increased levels are implicated in numerous breast cancer cases (Lehmann et al. 2013). Interestingly, a large multi-center study performed in Germany, Italy, Austria, and Spain did not identify any carriers of the rare rs12975333 allele to confirm these results (Peterlongo et al. 2011).

The rs2910164 G $\rightarrow$ C variant in miR-146a is a single nucleotide polymorphism whose deleterious function is mediated by two mechanisms: by impaired processing and downregulation of mature microRNA levels resulting in a diminished regulatory impact on target genes (Jazdzewski et al. 2008), and by creation of a new variant of the mature microRNA (Jazdzewski et al. 2009). Mature miRs are produced from both the $5 p$ and $3 p$ arms of the precursor mir-146a. The SNP is located in the seed region of miR-146a-3p, generating 2 isoforms that regulate distinct sets of target genes. Thus, homozygous carriers of GG or $\mathrm{CC}$ alleles produce 2 mature molecules (miR-146a-5p from the leading strand, and miR-146a$3 p(G)$ or $146 a-3 p(C)$, respectively, from the passenger strand), whereas GC heterozygotes produce 3 mature miRs: miR-146a-5p and both miR-146a-3p(G) and miR-146a-3p(C).

Importantly, $4.7 \%$ of thyroid tumors exhibited a somatic mutation in the SNP sequence that probably arose as a step in the clonal selection during carcinogenesis (Jazdzewski et al. 2008). Strikingly, all the identified somatic mutations occurred toward heterozygosity. The authors suggested that thyroid cells heterozygous at miR-146a presented higher activity of NF-kappaB and a lowered potential of inhibition of this pathway; therefore were more likely to survive after ionizing radiation, a known risk factor for thyroid cancer (Jazdzewski and de la Chapelle 2009).

The rs2910164 in miR-146a was shown to significantly predispose to papillary thyroid carcinoma (Jazdzewski et al. 2008), hepatocellular carcinoma (HCC) in males (Xu et al. 2008), prostate cancer (Xu et al. 2010), bladder cancer (Wang et al. 2012), and colorectal cancer (Ma et al. 2013), although not in all studied populations (Jones et al. 2012). It was also suggested that rs 2910164 can significantly contribute to the pathogenesis of breast cancer, as the target genes of miR-146a include BRCA1 and BRCA2, which are key breast and ovarian cancer genes. Breast cancer patients who had at least one miR-146a-variant allele were diagnosed at an earlier age than the patients with no variant alleles (Shen et al. 2008).

To what extent sequence variations in microRNA genes are associated with tumorigenesis became a matter of intensive investigation. Rs11614913 $(\mathrm{C} \rightarrow \mathrm{T})$ in a precursor of miR-196a2 was shown to impact the risk of non-small cell lung cancer (Hu et al. 2008; Tian et al. 2009; Yuan et al. 2013), esophageal cancer (Ye et al. 2008), breast cancer (Hoffman et al. 2009; Hu et al. 2009), HCC, 
and liver cirrhosis ( $\mathrm{Li}$ et al. 2010; Qi et al. 2010), as well as the overall survival of patients with advanced gastric cancer (Stenholm et al. 2013). This effect was explained by the fact that that presence of the rare $T$ allele severely lowers synthesis of both miRs expressed from the precursor and leads to altered gene recognition by the variant miR196a2-3p (Hoffman et al. 2009; Hu et al. 2008). Since the target genes for miR-196a include mediators of apoptosis and Hox genes, its aberrant expression can lead to severe changes in cellular pathways and initiate the process of tumorigenesis (Hornstein et al. 2005; Luthra et al. 2008).

Another polymorphism impairing the maturation of a miRNA and leading to inhibition of its function was rs895819 $(\mathrm{A} \rightarrow \mathrm{G})$ within miR-27a. The SNP has been proved to modify the risk for breast cancer in some populations (Kontorovich et al. 2010; Yang et al. 2010), but the effect was not observed in others (Catucci et al. 2012). The overall protective role associated with the rs895819 heterozygous state was proven for Caucasians in a recent metaanalysis (Wang et al. 2013). However, in advanced gastric cancer the SNP was associated with worse overall survival (Stenholm et al. 2013).

Although information on germline polymorphisms in microRNAs is growing, the occurrence of somatic mutations is generally much less well understood and less commonly identified. Research in this area was for a long time not a focus of interest and data are still lacking. It seems, however, that information on miRNA-related somatic mutations will soon be expanded. A recently published database, SomamiR, lists 26 somatic mutations that potentially affect the functioning of microRNAs in various diseases (Bhattacharya et al. 2013).

\section{SNPs in microRNA target sites}

Polymorphism in a $3^{\prime}$ UTR of a gene may create as well as destroy a miRNA-binding site and thus play a role similar to a SNP located within a miRNA seed region. The importance of the miRNA:mRNA interactions for the proper functioning of a cell was highlighted by a study demonstrating a significantly lower frequency of SNPs in the miRNA-binding sites than in the entire $3^{\prime}$ UTRs of genes (density 0.182 vs. $0.213 \mathrm{SNP} /$ kilobase). These data indicate that such SNPs are presumably negatively selected under evolutional pressure ( $\mathrm{Yu}$ et al. 2007). In consequence, the study underlined the role of miRNA disturbances in the pathogenesis of human diseases and, indeed, identified a number of SNPs with an aberrant allele frequency in human cancers. A recent release of miRdSNP, a database of disease-associated SNPs and microRNA-target sites located in $3^{\prime} \mathrm{UTR}$ s of human genes, includes 630 unique dSNPs and 786 SNP-disease associations (Bruno et al. 2012).
Studies have revealed the role of polymorphisms in microRNA recognition sites in the predisposition to particular malignancies, and by these means provided an additional proof of the implication of miRNA aberrations in the pathogenesis of cancers. A good example of a functional SNP located in a binding site for miRNA is rs61764370 $(\mathrm{G} \rightarrow \mathrm{T})$ within the $3^{\prime} \mathrm{UTR}$ of $K R A S$. Presence of the SNP interferes with let-7 binding, weakens the inhibition of KRAS expression and leads to over-activation of the Raf, PI3K, and growth factor signaling pathways. Rs61764370 was associated with an increased risk for non-small cell lung cancer (Chin et al. 2008), and reduced survival in patients with oral cancer (Christensen et al. 2009). The rare rs61764370 variant was also shown to modulate the response to cetuximab, an epidermal growth factor receptor inhibitor, in metastatic colorectal cancer patients (Zhang et al. 2011).

Another miRNA-related SNP that was shown to alter the response to therapies was the $829 \mathrm{C} \rightarrow \mathrm{T}$ SNP in DHFR gene, located within the binding site for miR-24. Dihydrofolate reductase is a target of methotrexate, an important antimetabolite and antifolate agent used in the treatment of malignancies including acute lymphocytic leukemia, nonHodgkin's lymphoma, osteosarcoma, or choriocarcinoma. Overexpression of DHFR caused by the loss of miR-24 binding results in resistance to methotrexate (Mishra et al. 2007).

\section{MicroRNA length heterogeneity}

Another intriguing subject related to the changes in miR sequences and the resulting alterations in their functioning is microRNA length heterogeneity. When next-generation sequencing was applied to microRNA analysis it became clear that an individual miRNA gene may give rise not only to the $5 p$ and $3 p$ mature miRNAs, but also to several additional miRNAs of varying length, named isomiRs (Kuchenbauer et al. 2008; Landgraf et al. 2007). Importantly, sequence variations of many of the isomiRs consist of the addition or deletion of nucleotides at their $5^{\prime}$ end when compared to the reference miRNA deposited in miRbase. This results in a change of the miR's seed region and, in consequence, leads to recognition and regulation of distinct sets of target genes. Thus, the effect of microRNA length variation can be similar to the effect mediated by microRNA polymorphisms (Fig. 1).

The "templated" isomiRs originate from imperfect specificity of both Drosha and Dicer cleavage of microRNA precursors, mainly due to asymmetrical structural motifs present in precursor hairpins (Neilsen et al. 2012; Starega-Roslan et al. 2011). MicroRNAs can also be trimmed by exonucleases, or extended, mainly at their $3^{\prime}$ ends, through the addition of ribonucleotides catalyzed 
Fig. 1 SNPs and length variations of microRNAs can alter the processing of a mature $\mathrm{miR}$ or directly change the seed region resulting in isoforms that regulate distinct target genes when compared to their canonical counterparts
Reference miRNA sequence

000000000000000000000000000 "canical" miR - 22nt

Isoforms with unaltered seed region

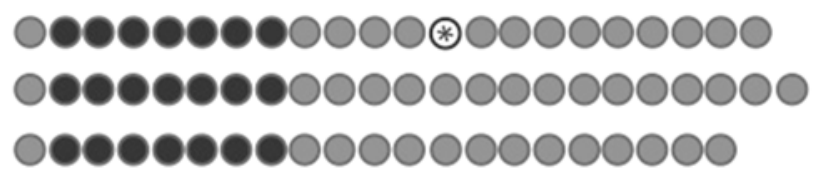

SNP outside the seed region

$22 n t+1$ at the 3 ' end

$22 n t-1$ at the 3 ' end

Isoforms with altered seed region

000\%000000000000000000

SNP in the seed region

○०000000000000000000

$22 \mathrm{nt}+1$ at the 5 ' end

$22 n t-1$ at the 5 ' end

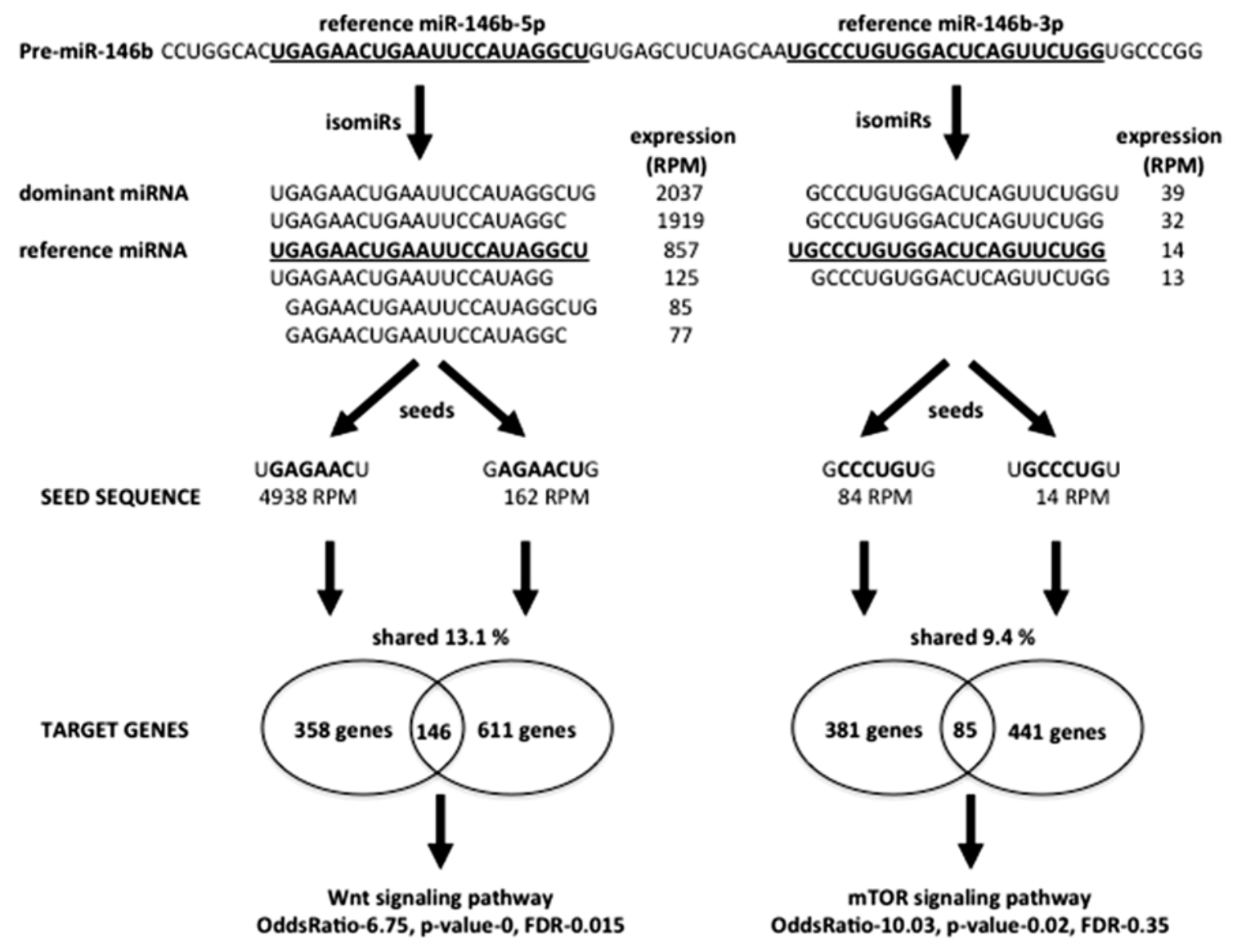

Fig. 2 Functional pathways of pre-miR-146b. Pre-miR-146b produces several isoforms of two canonical miRNAs (miR-146b-5p and miR-146b-3p). The isomiRs have four alternative seeds sequences, potentially binding unique sets of target genes. Shared target genes

by nucleotidyl transferases (Chiang et al. 2010; Cloonan et al. 2012; Kim 2005; Kuchenbauer et al. 2008; Landgraf et al. 2007; Lee et al. 2010; Swierniak et al. 2013). IsomiRs cooperatively regulate two important pathways implicated in tumorigenesis-Wnt and mTOR. RPM-reads per million in papillary thyroid carcinoma samples (mean count) (modified from Swierniak et al. 2013)

are tissue-specific and functionally active cooperative partners of canonical miRNAs (Cloonan et al. 2012). Although the role of isomiRs in the pathogenesis of cancers requires 
more studies, deregulation of isomiRs was already shown in a murine model of leukemia (Kuchenbauer et al. 2008) as well as in melanoma (Kozubek et al. 2013) and papillary thyroid carcinoma (Swierniak et al. 2013). Interestingly, all these studies showed that the most abundant mature sequence of most miRNAs differs from the canonical, reference sequence deposited in miRBase. In bone marrow cell lines, 336 identified miRNAs were expressed in 3,390 isoforms and the number of different isomiRs for a given miRNA ranged from 1 to 74 (Kuchenbauer et al. 2008). Another study identified isomiRs that exhibited different expression levels between primary cutaneous melanoma and metastatic melanoma (Kozubek et al. 2013). A recent study identified 427 reference microRNAs expressed in the thyroid gland, while the number of significantly expressed isomiRs reached 1749 (Swierniak et al. 2013). Many of the identified isomiRs were deregulated in cancer when compared to control tissue. One of the most striking examples of deregulated miRs were the products of the mir-146b precursor. Mir-146b is processed to two mature microRNAs: miR-146b-3p and miR-146b-5p. In thyroid tissue, these microRNAs are expressed altogether in 10 isoforms, and their expression in tumor samples was 14.4-39 times higher than in control tissue. In both cases, the reference sequences were not the dominant ones (Swierniak et al. 2013). The isoforms of both mature miRs vary at their $5^{\prime}$ ends with a 1 nt-difference, creating 2 alternative seeds each. In silico target prediction revealed that each seed binds a unique set of target genes, and only 13.1 and $9.4 \%$ of the target genes are regulated by the two highly expressed seeds of miR-146b-5p and miR-146b-3p, respectively (Fig. 2). The target genes shared by different isomiRs seem to be of particular interest, because their regulation is independent from the biases of Dicer activity. Moreover, the high number of isoforms increases their regulatory effect. The analysis of target genes concertedly regulated by both alternative seeds of miR-146b-5p and miR-146b-3p showed an overrepresentation of two pathways involved in tumorigenesis, namely Wnt-signaling pathway (Odds ratio 6.75, FDR 0.015), and mTOR-signaling pathway (Odds ratio 10.03, FDR 0.35), respectively (Swierniak et al. 2013, and unpublished data, Fig. 2).

Although microRNA research is a relatively young subject, a significant number of studies show the importance of microRNA-related sequence variations in the pathogenesis and susceptibility to particular malignancies. It is worth mentioning that the coordinate action of microRNA expression and sequence variations can differentially predispose to diseases in different populations, and can play divergent roles in different tissue types. As the number of identified miRs and polymorphisms are growing, this area will be constantly expanded and bring new insight into the role of miRs in human cancers.
Acknowledgments This work was supported by the Foundation for Polish Science: Programme FOCUS and Programme TEAM, co-financed by the European Union European Regional Development Fund, and by the Polish National Science Center grant no 2012/07/D/NZ3/04149. The Laboratory of Genomic Medicine of the Medical University of Warsaw, Poland participates in BASTION, a Program funded by the European Commission under the 7th Framework Program and by the Ministry of Science and Higher Education in Poland (FP7-REGPOT-2012-CT2012-316254-BASTION). Also supported by grants P30CA16058, P01CA124570 and P50CA168505 from the National Institutes of Health, USA.

Open Access This article is distributed under the terms of the Creative Commons Attribution License which permits any use, distribution, and reproduction in any medium, provided the original author(s) and the source are credited.

\section{References}

Auyeung VC, Ulitsky I, McGeary SE, Bartel DP (2013) Beyond secondary structure: primary-sequence determinants license primiRNA hairpins for processing. Cell 152:844-858. doi:10.1016/j. cell.2013.01.031

Bartel DP (2009) MicroRNAs: target recognition and regulatory functions. Cell 136:215-233

Bhattacharya A, Ziebarth JD, Cui Y (2013) SomamiR: a database for somatic mutations impacting microRNA function in cancer. Nucleic Acids Res 41:D977-D982. doi:10.1093/nar/gks1138

Bruno AE, Li L, Kalabus JL, Pan Y, Yu A, Hu Z (2012) miRdSNP: a database of disease-associated SNPs and microRNA target sites on $3^{\prime}$ UTRs of human genes. BMC Genomics 13:44. doi:10.1186/1471-2164-13-44

Calin GA, Dumitru CD, Shimizu M, Bichi R, Zupo S, Noch E, Aldler H, Rattan S, Keating M, Rai K, Rassenti L, Kipps T, Negrini M, Bullrich F, Croce CM (2002) Frequent deletions and down-regulation of micro-RNA genes miR15 and miR16 at 13q14 in chronic lymphocytic leukemia. Proc Natl Acad Sci USA 99:15524-15529

Calin GA, Ferracin M, Cimmino A, Di Leva G, Shimizu M, Wojcik SE, Iorio MV, Visone R, Sever NI, Fabbri M, Iuliano R, Palumbo T, Pichiorri F, Roldo C, Garzon R, Sevignani C, Rassenti L, Alder H, Volinia S, Liu CG, Kipps TJ, Negrini M, Croce CM (2005) A MicroRNA signature associated with prognosis and progression in chronic lymphocytic leukemia. N Engl J Med 353:1793-1801. doi:10.1056/NEJMoa050995

Catucci I, Verderio P, Pizzamiglio S, Bernard L, Dall'olio V, Sardella D, Ravagnani F, Galastri L, Barile M, Peissel B, Zaffaroni D, Manoukian S, Radice P, Peterlongo P (2012) The SNP rs895819 in miR-27a is not associated with familial breast cancer risk in Italians. Breast Cancer Res Treat 133:805-807. doi:10.1007/ s10549-012-2011-y

Chiang HR, Schoenfeld LW, Ruby JG, Auyeung VC, Spies N, Baek D, Johnston WK, Russ C, Luo S, Babiarz JE, Blelloch R, Schroth GP, Nusbaum C, Bartel DP (2010) Mammalian microRNAs: experimental evaluation of novel and previously annotated genes. Genes Dev 24:992-1009. doi:10.1101/gad.1884710

Chin LJ, Ratner E, Leng S, Zhai R, Nallur S, Babar I, Muller R-U, Straka E, Su L, Burki EA, Crowell RE, Patel R, Kulkarni T, Homer R, Zelterman D, Kidd KK, Zhu Y, Christiani DC, Belinsky SA, Slack FJ, Weidhaas JB (2008) A SNP in a let-7 microRNA complementary site in the KRAS $3^{\prime}$ untranslated region increases non-small cell lung cancer risk. Cancer Res 68:85358540. doi:10.1158/0008-5472.can-08-2129

Christensen BC, Moyer BJ, Avissar M, Ouellet LG, Plaza SL, McClean MD, Marsit CJ, Kelsey KT (2009) A let-7 
microRNA-binding site polymorphism in the KRAS $3^{\prime}$ UTR is associated with reduced survival in oral cancers. Carcinogenesis 30:1003-1007. doi:10.1093/carcin/bgp099

Cloonan N, Wani S, Xu Q, Gu J, Lea K, Heater S, Barbacioru C, Steptoe AL, Martin HC, Nourbakhsh E, Krishnan K, Gardiner B, Wang X, Nones K, Steen JA, Matigan N, Wood DL, Kassahn KS, Waddell N, Shepherd J, Lee C, Ichikawa J, McKernan K, Bramlett K, Kuersten S, Grimmond SM (2012) MicroRNAs and their isomiRs function cooperatively to target common biological pathways. Genome Biol 12:R126. doi:10.1186/gb-2011-12-12-r126

de la Chapelle A, Jazdzewski K (2011) MicroRNAs in thyroid cancer. J Clin Endocrinol Metab 96:3326-3336. doi:10.1210 /jc.2011-1004

Duan R, Pak C, Jin P (2007) Single nucleotide polymorphism associated with mature miR-125a alters the processing of pri-miRNA. Hum Mol Genet 16:1124-1131. doi:10.1093/hmg/ddm062

Friedman RC, Farh KK, Burge CB, Bartel DP (2009) Most mammalian mRNAs are conserved targets of microRNAs. Genome Res 19:92-105

Gottwein E, Cai X, Cullen BR (2006) A novel assay for viral microRNA function identifies a single nucleotide polymorphism that affects drosha processing. J Virol 80:5321-5326. doi:10.1128/ jvi.02734-05

Griffiths-Jones S, Saini HK, van Dongen S, Enright AJ (2008) miRBase: tools for microRNA genomics. Nucleic Acids Res 36:D154-D158. doi:10.1093/nar/gkm952

Grimson A, Farh KK, Johnston WK, Garrett-Engele P, Lim LP, Bartel DP (2007) MicroRNA targeting specificity in mammals: determinants beyond seed pairing. Mol Cell 27:91-105

Hoffman AE, Zheng T, Yi C, Leaderer D, Weidhaas J, Slack F, Zhang Y, Paranjape T, Zhu Y (2009) microRNA miR-196a-2 and breast cancer: a genetic and epigenetic association study and functional analysis. Cancer Res 69:5970-5977. doi:10.1158/0008-5472. CAN-09-0236

Hornstein E, Mansfield JH, Yekta S, Hu JK, Harfe BD, McManus MT, Baskerville S, Bartel DP, Tabin CJ (2005) The microRNA miR-196 acts upstream of Hoxb8 and Shh in limb development. Nature 438:671-674. doi:10.1038/nature04138

Hu Z, Chen J, Tian T, Zhou X, Gu H, Xu L, Zeng Y, Miao R, Jin G, Ma H, Chen Y, Shen H (2008) Genetic variants of miRNA sequences and non-small cell lung cancer survival. J Clin Invest 118:2600-2608. doi:10.1172/JCI34934

Hu Z, Liang J, Wang Z, Tian T, Zhou X, Chen J, Miao R, Wang Y, Wang X, Shen H (2009) Common genetic variants in pre-microRNAs were associated with increased risk of breast cancer in Chinese women. Hum Mutat 30:79-84

Iwai N, Naraba H (2005) Polymorphisms in human pre-miRNAs. Biochem Biophys Res Commun 331:1439-1444

Jazdzewski K, de la Chapelle A (2009) Genomic sequence matters: a SNP in microRNA-146a can turn anti-apoptotic. Cell Cycle 8:1642-1643

Jazdzewski K, Murray EL, Franssila K, Jarzab B, Schoenberg DR, de la Chapelle A (2008) Common SNP in pre-miR-146a decreases mature miR expression and predisposes to papillary thyroid carcinoma. Proc Natl Acad Sci USA 105:7269-7274. doi:10.1073/p nas.0802682105

Jazdzewski K, Liyanarachchi S, Swierniak M, Pachucki J, Ringel MD, Jarzab B, de la Chapelle A (2009) Polymorphic mature microRNAs from passenger strand of pre-miR-146a contribute to thyroid cancer. Proc Natl Acad Sci USA 106:1502-1505. doi:10. 1073/pnas.0812591106

Jones AM, Howarth KM, Martin L, Gorman M, Mihai R, Moss L, Auton A, Lemon C, Mehanna H, Mohan H, Clarke SE, Wadsley J, Macias E, Coatesworth A, Beasley M, Roques T, Martin C, Ryan P, Gerrard G, Power D, Bremmer C, Tomlinson I, Carvajal-Carmona LG (2012) Thyroid cancer susceptibility polymorphisms: confirmation of loci on chromosomes $9 \mathrm{q} 22$ and $14 \mathrm{q} 13$, validation of a recessive $8 \mathrm{q} 24$ locus and failure to replicate a locus on 5q24. J Med Genet 49:158-163. doi:10.1136/jme dgenet-2011-100586

Kim VN (2005) MicroRNA biogenesis: coordinated cropping and dicing. Nat Rev Mol Cell Biol 6:376-385. doi:10.1038/nrm1644

Kontorovich T, Levy A, Korostishevsky M, Nir U, Friedman E (2010) Single nucleotide polymorphisms in miRNA binding sites and miRNA genes as breast/ovarian cancer risk modifiers in Jewish high-risk women. Int J Cancer 127:589-597. doi:10.1002/ijc.25065

Kozomara A, Griffiths-Jones S (2011) miRBase: integrating microRNA annotation and deep-sequencing data. Nucleic Acids Res 39:D152-D157. doi:10.1093/nar/gkq1027

Kozubek J, Ma Z, Fleming E, Duggan T, Wu R, Shin DG, Dadras SS (2013) In-depth characterization of microRNA transcriptome in melanoma. PLoS ONE 8:e72699. doi:10.1371/ journal.pone.0072699

Krol J, Loedige I, Filipowicz W (2010) The widespread regulation of microRNA biogenesis, function and decay. Nat Rev Genet 11:597-610. doi:10.1038/nrg2843

Kuchenbauer F, Morin RD, Argiropoulos B, Petriv OI, Griffith M, Heuser M, Yung E, Piper J, Delaney A, Prabhu A-L, Zhao Y, McDonald H, Zeng T, Hirst M, Hansen CL, Marra MA, Humphries RK (2008) In-depth characterization of the microRNA transcriptome in a leukemia progression model. Genome Res 18:1787-1797. doi:10.1101/gr.077578.108

Landgraf P, Rusu M, Sheridan R, Sewer A, Iovino N, Aravin A, Pfeffer S, Rice A, Kamphorst AO, Landthaler M, Lin C, Socci ND, Hermida L, Fulci V, Chiaretti S, Foa R, Schliwka J, Fuchs U, Novosel A, Muller RU, Schermer B, Bissels U, Inman J, Phan Q, Chien M, Weir DB, Choksi R, De Vita G, Frezzetti D, Trompeter HI, Hornung V, Teng G, Hartmann G, Palkovits M, Di Lauro R, Wernet P, Macino G, Rogler CE, Nagle JW, Ju J, Papavasiliou FN, Benzing T, Lichter P, Tam W, Brownstein MJ, Bosio A, Borkhardt A, Russo JJ, Sander C, Zavolan M, Tuschl T (2007) A mammalian microRNA expression atlas based on small RNA library sequencing. Cell 129:1401-1414

Lee LW, Zhang S, Etheridge A, Ma L, Martin D, Galas D, Wang K (2010) Complexity of the microRNA repertoire revealed by next-generation sequencing. RNA 16:2170-2180. doi:10.1261/ rna. 2225110

Lehmann TP, Korski K, Ibbs M, Zawierucha P, Grodecka-Gazdecka S, Jagodzinski PP (2013) rs12976445 variant in the pri-miR125a correlates with a lower level of hsa-miR-125a and ERBB2 overexpression in breast cancer patients. Oncol Lett 5:569-573. doi: $10.3892 /$ ol 2012.1040

Li W, Duan R, Kooy F, Sherman SL, Zhou W, Jin P (2009) Germline mutation of microRNA-125a is associated with breast cancer. $\mathrm{J}$ Med Genet 46:358-360. doi:10.1136/jmg.2008.063123

Li XD, Li ZG, Song XX, Liu CF (2010) A variant in microRNA$196 \mathrm{a} 2$ is associated with susceptibility to hepatocellular carcinoma in Chinese patients with cirrhosis. Pathology 42:669-673. doi: 10.3109/00313025.2010.522175

Liu C, Zhang F, Li T, Lu M, Wang L, Yue W, Zhang D (2012) MirSNP, a database of polymorphisms altering miRNA target sites, identifies miRNA-related SNPs in GWAS SNPs and eQTLs. BMC Genomics 13:661. doi:10.1186/1471-2164-13-661

Luthra R, Singh RR, Luthra MG, Li YX, Hannah C, Romans AM, Barkoh BA, Chen SS, Ensor J, Maru DM, Broaddus RR, Rashid A, Albarracin CT (2008) MicroRNA-196a targets annexin A1: a microRNA-mediated mechanism of annexin A1 downregulation in cancers. Oncogene 27:6667-6678. doi:10.1038/onc.2008.256

Ma L, Zhu L, Gu D, Chu H, Tong N, Chen J, Zhang Z, Wang M (2013) A genetic variant in miR-146a modifies colorectal cancer susceptibility in a Chinese population. Arch Toxicol 87:825-833. doi:10.1007/s00204-012-1004-2 
Mishra PJ, Humeniuk R, Mishra PJ, Longo-Sorbello GS, Banerjee D, Bertino JR (2007) A miR-24 microRNA binding-site polymorphism in dihydrofolate reductase gene leads to methotrexate resistance. Proc Natl Acad Sci USA 104:13513-13518

Neilsen CT, Goodall GJ, Bracken CP (2012) IsomiRs-the overlooked repertoire in the dynamic microRNAome. Trends Genet 28:544549. doi:10.1016/j.tig.2012.07.005

Peterlongo P, Caleca L, Cattaneo E, Ravagnani F, Bianchi T, Galastri L, Bernard L, Ficarazzi F, Dall'olio V, Marme F, Langheinz A, Sohn C, Burwinkel B, Giles GG, Baglietto L, Severi G, Odefrey FA, Southey MC, Osorio A, Fernandez F, Alonso MR, Benitez J, Barile M, Peissel B, Manoukian S, Radice P (2011) The rs12975333 variant in the miR-125a and breast cancer risk in Germany, Italy, Australia and Spain. J Med Genet 48:703-704. doi:10.1136/jmedgenet-2011-100103

Qi P, Dou TH, Geng L, Zhou FG, Gu X, Wang H, Gao CF (2010) Association of a variant in MIR 196A2 with susceptibility to hepatocellular carcinoma in male Chinese patients with chronic hepatitis B virus infection. Hum Immunol 71:621-626. doi:10.1016/j.humimm.2010.02.017

Rodriguez A, Griffiths-Jones S, Ashurst JL, Bradley A (2004) Identification of mammalian microRNA host genes and transcription units. Genome Res 14:1902-1910. doi:10.1101/gr.2722704

Saunders MA, Liang H, Li WH (2007) Human polymorphism at microRNAs and microRNA target sites. Proc Natl Acad Sci USA 104:3300-3305

Shen J, Ambrosone CB, DiCioccio RA, Odunsi K, Lele SB, Zhao H (2008) A functional polymorphism in the miR-146a gene and age of familial breast/ovarian cancer diagnosis. Carcinogenesis 29:1963-1966

Starega-Roslan J, Krol J, Koscianska E, Kozlowski P, Szlachcic WJ, Sobczak K, Krzyzosiak WJ (2011) Structural basis of microRNA length variety. Nucleic Acids Res 39:257-268. doi:10.1093/nar/ gkq727

Stenholm L, Stoehlmacher-Williams J, Al-Batran SE, Heussen N, Akin S, Pauligk C, Lehmann S, Senff T, Hofheinz RD, Ehninger G, Kramer M, Goekkurt E (2013) Prognostic role of microRNA polymorphisms in advanced gastric cancer: a translational study of the Arbeitsgemeinschaft Internistische Onkologie (AIO). Ann Oncol 24:2581-2588. doi:10.1093/annonc/mdt330

Swierniak M, Wojcicka A, Czetwertynska M, Stachlewska E, Maciag M, Wiechno W, Gornicka B, Bogdanska M, Koperski L, de la Chapelle A, Jazdzewski K (2013) In-depth characterization of the microRNA transcriptome in normal thyroid and papillary thyroid carcinoma. J Clin Endocrinol Metab 98:E1401-E1409. doi:10.12 10/jc.2013-1214
Tian T, Shu Y, Chen J, Hu Z, Xu L, Jin G, Liang J, Liu P, Zhou X, Miao R, Ma H, Chen Y, Shen H (2009) A functional genetic variant in microRNA-196a2 is associated with increased susceptibility of lung cancer in Chinese. Cancer Epidemiol Biomarkers Prev 18:1183-1187. doi:10.1158/1055-9965.EPI-08-0814

Wang M, Chu H, Li P, Yuan L, Fu G, Ma L, Shi D, Zhong D, Tong N, Qin C, Yin C, Zhang Z (2012) Genetic variants in miRNAs predict bladder cancer risk and recurrence. Cancer Res 72:61736182. doi:10.1158/0008-5472.CAN-12-0688

Wang Z, Lai J, Wang Y, Nie W, Guan X (2013) The Hsa-miR-27a rs895819 (A>G) polymorphism and cancer susceptibility. Gene 521:87-90. doi:10.1016/j.gene.2013.02.042

Xu T, Zhu Y, Wei QK, Yuan Y, Zhou F, Ge YY, Yang JR, Su H, Zhuang SM (2008) A functional polymorphism in the miR-146a gene is associated with the risk for hepatocellular carcinoma. Carcinogenesis 29:2126-2131

Xu B, Feng NH, Li PC, Tao J, Wu D, Zhang ZD, Tong N, Wang JF, Song NH, Zhang W, Hua LX, Wu HF (2010) A functional polymorphism in Pre-miR-146a gene is associated with prostate cancer risk and mature miR-146a expression in vivo. Prostate 70:467-472. doi:10.1002/pros.21080

Yang R, Schlehe B, Hemminki K, Sutter C, Bugert P, Wappenschmidt B, Volkmann J, Varon R, Weber BH, Niederacher D, Arnold N, Meindl A, Bartram CR, Schmutzler RK, Burwinkel B (2010) A genetic variant in the pre-miR-27a oncogene is associated with a reduced familial breast cancer risk. Breast Cancer Res Treat 121:693-702. doi:10.1007/s10549-009-0633-5

Ye Y, Wang KK, Gu J, Yang H, Lin J, Ajani JA, Wu X (2008) Genetic variations in microRNA-related genes are novel susceptibility loci for esophageal cancer risk. Cancer Prev Res (Phila) 1:460469. doi:10.1158/1940-6207.CAPR-08-0135

Yu Z, Li Z, Jolicoeur N, Zhang L, Fortin Y, Wang E, Wu M, Shen SH (2007) Aberrant allele frequencies of the SNPs located in microRNA target sites are potentially associated with human cancers. Nucleic Acids Res 35:4535-4541. doi:10.1093/nar/gkm480

Yuan Z, Zeng X, Yang D, Wang W, Liu Z (2013) Effects of common polymorphism rs11614913 in hsa-miR-196a2 on lung cancer risk. PLoS ONE 8:e61047. doi:10.1371/journal.pone.0061047

Zhang W, Winder T, Ning Y, Pohl A, Yang D, Kahn M, Lurje G, Labonte MJ, Wilson PM, Gordon MA, Hu-Lieskovan S, Mauro DJ, Langer C, Rowinsky EK, Lenz HJ (2011) A let-7 microRNAbinding site polymorphism in $3^{\prime}$-untranslated region of KRAS gene predicts response in wild-type KRAS patients with metastatic colorectal cancer treated with cetuximab monotherapy. Ann Oncol 22:104-109. doi:10.1093/annonc/mdq315 